\title{
COMMODIFICATION AND DISINFORMATION IN THE CONJURING II FILM
}

\section{WIDAYATMOKO DAN \& NOPPY ANGREANI}

Faculty of Communication, Tarumanagara University, Jakarta

\begin{abstract}
At this time, changes in the value of the use of products into selling value not only for goods and services, but cultural values, religion, and information are also used as a commodity that is apprehended may damage the originality of these values. This cannot be separated from the intense of capitalism impact to gain the maximum profit to make anything as a commodity that can be sold. Consequently, many disinformations is widespread in the community and thus are believed to be a true information. The Conjuring II film often presents the results of commodification and disinformation form to various aspects such as stories, figures, up to religious symbols of Catholicism. Referring to the above, the purpose of this study is to find out the forms of commodification and disinformation contained in The Conjuring II film. Commodification according to Vincent Mosco (2009) is the process of changing the benefit value of objects into selling value. The process of changing the benefit value into selling value conduct of the media, has led to the excessive symbol production and then obscures the original meaning of the symbol called as disinformation (Mufid, 2012). This research method uses descriptive qualitative research with critical paradigm and semiotics analysis technique by Roland Barthes. The Conjuring II film was based on a true story, supplemented with many scenes and new characters. Religious symbols of Catholic such as crosses and nun are also dominantly showed but not with their original meaning, but in the form of commodified disinformation. The enormous earnings of The Conjuring II film show that the practice of commodification by means of disinformation has made a profit. The practice of commodification is based on the objective of the capitalist to achieve the greatest benefit which leads to the disinformation of the meaning of symbols on the cross and nuns.

KEYWORDS: Commodification, Disinformation, Film \& Symbol
\end{abstract}

Received: Feb 12, 2018, Accepted: Mar 02, 2018, Published: Mar 22, 2018, Paper Id: IJCMSAPR20182

\section{INTRODUCTION}

Everything that is used as a product and sold to the community is called as commodification activity, which is the process of changing the benefit value into selling value (Mosco, 2009). Currently, the change of product benefit value into a selling value not only on goods and services, but cultural values, religion, and information are also used as commodities. Commodities of cultural, religious and informational values are worried to undermine originality and diminish the capacity of human ability to understand the values of culture, religion, and information itself. This cannot be separated from the forcefulness of capitalism push to gain the maximum profit to make anything as a commodity that can be sold.

Cultural, religious, and information values that are commodified in such a way can also be referred to as disinformation activity, which is the activity of altering the content of messages or information intentionally for a particular purpose. (https://www.suara.com/tekno/2017/05/15/232015/ini-7-jeniskonten-misinformasi-da ndisinformasi. Retrieved on 8 September 2017, 20:12 Western Indonesian Time). Disinformation can be regarded as a practice of commodification if the purpose of disinformation activity is to gain profit. The communication media 
has evolved toward a point in which there is a discontinuation of communication function, the confusion of symbol, the obscuring of meaning, the distortion of reality, and the eradication of truth. Communication no longer has a definite purpose; information no longer has a clear meaning. At this moment, there is no definite boundary between truth and falsehood. Therefore, the truth in the mass media becomes crucial because the truth of the media version is sometimes different from the community version. This is because the application of truth in the media is influenced by the environment surrounding the media, such as owners of capital and advertisers (Mufid, 2009). It is therefore difficult to distinguish between commodity and non- commodity information.

It is unfortunate if the media becomes a commercial space that prioritizes the interests of the capitalist. The media will no longer create quality products, but more focus on producing marketable products that sell in the market. The practice of commodification according to Mosco (2009) on the media is marked by the change of content or media content into commodities to gain profit, one of which is the film. Essentially, all films are social and cultural documents that help communicate the times when the film was made even though it was never meant for it (Ibrahim, 2011). The messages in the film are packaged in such a way as to attract the audience and can be sold in a market which then forms a pseudo hyperreality and trusted the community as reality itself (Martadi, 2003). Hyper-reality in the film, which is a disinformation with the aim to gain profit and made as the commodity. The connection between commodification and disinformation in the film makes it interesting to examine. There should be special attention toward commodification and disinformation in a film, whether the level of commodification and disinformation has reached the point that gives a negative impact to the community or exactly a positive impact.

The Conjuring II film is a franchise film from The Conjuring (2013) which is the world's best horror film positioned in the 1st rank based on period 1980 to 2018 (http://www.boxofficemojo.com/genres/chart/? Id=horror period.Htm.on September 8, 2017, at 6:43 pm). The Conjuring film is familiar with the elements of Catholicism, the religious symbol of Catholicism is much shown because it raises the true story that encountered by a couple of Catholic demonologists named Ed and Lorraine Warren. Seeing the success of The Conjuring film, then The Conjuring II film was made in 2016 which also raised the real story of Ed and Lorraine Warren in 1977, which is The Enfield Poltergeist Case. The real story of The Enfield Poltergeist Case tells of the Hodgson family at Enfield who suffered from an invisible force, a ghost annoyance.

After the Conjuring II film showed on June 10, 2016 until August 25, 2016 it directly, becomes the public topic because, in addition to an interesting story, the main antagonist figure is also considered unique that is a nun demon named Valak. The figure of Valak became phenomenal and popular indicated from the number of Valak Me-Me in social media, make-up video tutorials Valak on youtube, until made as Halloween costumes. This shows that the figure of a nun has been considered as a product by The Conjuring II production team and also by the public. The figure of a nun who has the meaning of a woman living in a monastery or community, who pledge herself to devotion to God and service in the church through three vows: vow of poverty, vow of virginity, and the vow of obedience (Magis-Suseno, 2017), is presented as a demon which eventually turned into entertainment and comedy product by the community. In addition to commodification, the figure of a nun also experiences disinformation because it is not displayed as it is. The form of commodification and disinformation in The Conjuring II film is not only on the figure of a nun, but also on various other aspects that will be discussed more deeply in this study. Based on the above, the main purpose of this research is to find out the form of commodification and disinformation contained in The Conjuring II film. 


\section{LITERATURE REVIEW}

\section{Commodification}

Commodification is defined as a process associated with capitalism (Barker, 2015). The current capitalism that has dominated the economic life, educates and selects the economic subjects it needs through a process of the best economic survival (Weber, 2005). Objects, qualities, and symbol are converted into commodities, that is, which primary purpose is to sell in the marketplace. The concept of commodification refers to the utilization of goods and services viewed from its usefulness which is then transformed into a commodity valued by its meaning in the market. The point is commodification is the process of benefit, value transformation to be the exchange value (Mosco, 2009). While being exchanged not only the goods, consumer needs, but also the symbols of religion, culture, social, and art.

In connection to this, McQuail (2010) explains that political economy theory is a social critique approach that focuses on the relationship between the economic structure and the dynamics of the media industry as well as the ideological content of the media. McQuail (2010) describes some of the major propositions of the media politics' economic theory:

- Control of the economy and logic is always decisive.

- The structure of the media always tends toward monopoly.

- The global integration of media ownership is growing.

- Content and audiences are used as commodities (commodification).

- The real diversity decreases.

- Opposition and alternative votes are marginalized.

- The public interest is set aside for personal benefit.

- Access to communication benefits is spread unevenly.

As for the forms of commodification in the political economy of media according to Mosco (2009) is divided into 3, namely:

1. The commodification of Content, which is the process of changing the message of the collection of information into the system of meaning in the form of marketable products.

2. The commodification of Audience, which is the process of modifying the message of readers or audiences by media companies and advertisers. Media companies produce audiences through a program /show to be subsequently sold to advertisers.

- Intrinsic Commodification: is a media process to exchange with the rating. This commodity is embedded directly from the program created marked by the number of advertisers drawn in the certain programs show.

- Extrinsic Commodification: The process of commodification that occurs and expands, involving educational institutions, government, culture, telecommunications and so on.

3. The commodification of Labor, which is a transformation of work processes within capitalism, where the 
craftsmanship and working hours of workers are commodified and rewarded with salary.

\section{Disinformation}

The communication media has evolved toward a point in which there is a discontinuation of the communication function, the confusion of symbol, the obscuring of meaning, the distortion of reality, and the eradication of truth. Communication no longer has a definite purpose; information no longer has a clear meaning. Information evolves toward superlative properties, produced in excessive portions called disinformation. There is now no definite boundary between truth and falsehood. People are faced with great difficulties in separating between truth and falsehood (Mufid, 2009).

Falsehood was packaged intelligently through the manipulation of computer graphics, can now emerge as a convincing truth. Therefore, the truth in the mass media becomes crucial because the truth of the media version is sometimes different from the community version. The application of truth in the media is influenced by the environment surrounding the media, such as capital owners and advertisers (Mufid, 2009).

\section{Film}

The Film is a moving picture, a mass communication media to communicate about a reality that occurs in everyday life and has a strong reality, one of which tells about the reality of society.

(http://www.landasanteori.com/2015/10/pengertian-film-definisi-menu rut-para.html. Retrieved on November 25, 2017, 17.09 Western Indonesian Time). The power and capability of the film in reaching many social segments, then make the experts argue that the film has the potency to influence the audience (Sobur, 2003). Through the messages contained in it, a film is able to influence and even change and shape the character of the audience.

A film that fully loaded with symbols, signs, or the icons will tend to be full of interpretation. An innovative thing with nature of high appreciation, thereby offering possibly new knowledge, or something that is reminiscent of something that has been known before. A film that promotes results in marketing or commercial, will always follow the sense of the market, although the challenge of a film is to make it happen (Romli, 2016).

\section{Research Method}

This research uses qualitative research methodology. Qualitative research is a research method used to examine the condition of natural objects, where researcher as a key instrument, data analysis is inductive, and qualitative research results in more emphasis on the meaning of the generalization (Sugiyono, 2016). The type of research is descriptive qualitative aimed to describe the phenomena that exist, both natural phenomena and man-made phenomena (Sukmadinata, 2006). The paradigm used is a critical paradigm. Researchers want to criticize the form of commodification and disinformation that existed in The Conjuring II film. Not only in the figure of nuns, various aspects also experience disinformation and commodified in such a way for the purposes of entertainment.

The subject of this research is The Conjuring II film and the object of research is a form of commodification and disinformation. The data analysis technique used is Roland Barthes semiotics which makes a systematic model in analyzing the meaning of the signs. Barthes believes that the relationship between sign and symbol does not form naturally. In addition, Barthes also saw another aspect of the sign, which is a myth that marks a society (Vera, 2014). According to Barthes, myths are different from the myths in the general sense. Myth in a special meaning is the development of longestablished connotations in society. Barthes also said that myth is a semiological system, the system of signs that are 
interpreted by a human (Hoed, in Vera, 2014).

\section{FINDINGS}

\section{The Conjuring II Film Synopsis}

The Conjuring II Film Synopsis In 1975, a Catholic demonologists couple Ed and Lorraine Warren visited Amityville's home at the request of the Lutz family who claimed they felt a supernatural phenomenon in their house. Lorraine then meets a demon form of a nun in the Amityville house warehouse. The demon showed Lorraine the way an unknown man died. After the incident, Lorraine did not want to do any spiritual activity or exorcism for some time.

Three years later, in Enfield, England, the Hodgson family consisted of a mother named Peggy Hodgson with four children, 12 Margaret, Janet, Johnny, and Billy suffered a distraction from invisible creatures in their house. Day after day, Janet's behavior became strange, often possessed, and things inside the house moved on their own. Some investigators say that there are not sufficient evidences to suggest that the event is real. The only real proof is Janet's voice recording that turns into the voice of an old grandfather and claims to be named Bill Wilkins (72 years).

The Catholic Church is willing to help solving the Hodgson family's problems by asking for help from Ed and Lorraine Warren for an investigation for 3 days. But there was a big puzzle and mystery behind the Hodgson family case that no one knew, from The Crooked Man, to the figure of a demon of a nun who haunted Lorraine. So began a real struggle for the demonologist and Hodgson's family in the fighting against the demon who had been very smart to cover her existence. (http://www.imdb.com/title/tt3065204/plotsummary?ref=ttstrypl\#synopsis. Retrieved on 8 October 2017, 02:31 Western Indonesian Time).

\section{Analysis}

If the story of The Conjuring II film compared with the real story of The Enfield Poltergeist Case, it will look the difference between the two. There are many scenes and some extra characters in The Conjuring II film which is not actually in the real event of The Enfield Poltergeist. The involvement of the demonologist Ed and Lorraine Warren couple is also not as great as that featured in The Conjuring II film. The ghosts who disturb the Hodgson family are actually only 1, Bill Wilkins. The Crooked Man and the nun demon are additional characters and made by the director.

The dense element of Catholicism in The Conjuring II film is also an additional element because there is no involvement of symbols or Catholicism ideology on various documentation of the incident The Enfield Poltergeist. The Catholic religion is shown because the main character of The Conjuring II film is Ed and Lorraine Warren, who are Catholic so their culture, customs, and beliefs are also featured. Seeing the many additional elements to the real story of The Enfield Poltergeist in The Conjuring II film then it can be said that there is a commodification practice done by a film production team to be able to build an interesting, unique, and can complete story with other films. The Enfield Poltergeist's story is not displayed as it is but it tends to be exaggerated. Religious symbols of Catholicism such as crosses and nuns are also not displayed according to their original meaning.

Here is an extraction of the scenes in The Conjuring II film showing the practice of commodification and disinformation, as follows: 
Table 1 : Semiotics Analysis of The Conjuring II Film

\begin{tabular}{|c|c|c|c|c|}
\hline SI. No & Scene & Denotation & Connotation & Myth \\
\hline 1. & & $\begin{array}{l}\text { - The figure of a crucified } \\
\text { and white-facad num } \\
\text { - A woman was surprised } \\
\text { to see the figure. }\end{array}$ & $\begin{array}{l}\text { - The nun is not human but the } \\
\text { embodiment of the demon. } \\
\text { - Nuns are not always good. } \\
\text { The cross has no power } \\
\text { against the demon. }\end{array}$ & $\begin{array}{l}\text { - The symbol of the cross } \\
\text { is believed to have the } \\
\text { power to drive out evil } \\
\text { spirits. }\end{array}$ \\
\hline 2. & & $\begin{array}{l}\text { The scattered room. } \\
\text { Many crosses were } \\
\text { hanging on the wall }\end{array}$ & $\begin{array}{l}\text { - The room was not used } \\
\text { because of the evil spirits. } \\
\text { - The cross is believed to drive } \\
\text { out evil spirits. } \\
\text { - The cross has no power to cast } \\
\text { out evil spirits because the } \\
\text { rooms arestill not used. }\end{array}$ & $\begin{array}{l}\text { - The symbol of the cross } \\
\text { is believed to have the } \\
\text { power to drive out evil } \\
\text { spirits. }\end{array}$ \\
\hline 3. & & $\begin{array}{l}\text { - Bill's figure came up. Ed } \\
\text { took out his cross and } \\
\text { pointed it at Bill. } \\
\text { When Ed's cross was } \\
\text { getting closer to Bill, } \\
\text { Bill's figure dis appeared } \\
\text { and Janet's figure was } \\
\text { visible. }\end{array}$ & $\begin{array}{l}\text { The dis appear of Bill's figure } \\
\text { and the appearanoe of Janet's } \\
\text { figure shows that Ed's cross } \\
\text { had the power it feared, God's } \\
\text { power. }\end{array}$ & $\begin{array}{l}\text { - The symbol of the cross } \\
\text { is believed to have the } \\
\text { power to drive out evil } \\
\text { spirits. } \\
\text { The symbol of the cross } \\
\text { have the power to drive } \\
\text { out evil spirits. }\end{array}$ \\
\hline 4. & & $\begin{array}{l}\text { - The cros ses one by ona } \\
\text { lead in the opposite } \\
\text { direction. } \\
\text { - After the entire cross in } \\
\text { the room was reversed, } \\
\text { Bill emerged from the } \\
\text { darkness and attacked } \\
\text { Janet from the right. }\end{array}$ & $\begin{array}{l}\text { - The cros ses in the room have } \\
\text { no power. } \\
\text { Bill's appearance after the } \\
\text { entire cross in Janet's bedroom } \\
\text { turned up side down, giving the } \\
\text { impres sion that the reverse } \\
\text { cross is a symbol of the } \\
\text { appearance of evil spirits. }\end{array}$ & $\begin{array}{l}\text { - The symbol of the cross } \\
\text { is believed to have the } \\
\text { power to drive out evil } \\
\text { spirits. } \\
\text { The reverse cross is an } \\
\text { antiCatholic symbol and } \\
\text { a symbol of the presence } \\
\text { of evil spirits and the } \\
\text { symbol of Satan. }\end{array}$ \\
\hline 5. & & $\begin{array}{l}\text { - Nun-looking demon } \\
\text { smiled. } \\
\text { Her eyes were yellow, } \\
\text { her lips were black, and } \\
\text { her teeth were covered in } \\
\text { blood. } \\
\text { There was an upside- } \\
\text { down cross on the left of } \\
\text { the nun looking demon. }\end{array}$ & $\begin{array}{l}\text { Her smile was full of } \\
\text { deceptiveness. } \\
\text { The turned upside down cross } \\
\text { showed that the appearance of } \\
\text { demon indicated with reversed } \\
\text { cross. } \\
\text { The cross symbol has no } \\
\text { power. }\end{array}$ & $\begin{array}{l}\text { The symbol of the cross } \\
\text { is believed to have the } \\
\text { power to drive out evil } \\
\text { spirits. } \\
\text { The reverse cross is an } \\
\text { anti Catholic symbol and } \\
\text { a symbol of the presence } \\
\text { of evil spirits and the } \\
\text { symbol of Satan. }\end{array}$ \\
\hline
\end{tabular}

Source: Researcher's Documentation (2017)

\section{Analysis of Commodification}

The Conjuring II film type is semi-documentary because it reveals the true story that has happened in the past, but its fictitious content and fact range from $40 \%$ to $60 \%$ of the entire film (https: //twitter.com/bangkumerahh. Retrieved on 25th November 2017, 21:09 Western Indonesian Time). The name of the character and some of the scenes are exactly the same as the original events, but there are also additional stories and made by the director. Some scenes such as inverted crosses, The Crooked Man's disturb, Valak's appearance, the expulsion of the demon made by Lorraine, and various other scenes, did not occur in the real fact of The Enfield Poltergeist. (http://www.historyvshollywood.com/reelfaces/conjuring2enfield-polter geist/. Retrieved on 10 October 2017, 23:44 Western Indonesian Time).

The Conjuring II film genre is horror, thriller, and mystery. The horror genre offers the sensation of horror by displaying frightening events to the audience, the thriller genre offers a tense sensation that seized, and the mystery genre offers a mystery of puzzles and mysterious events that make the audience full of curiosity. Based on the genre, the purpose of the story and the additional scene is to build a horror, suspense, and mysterious sensation that adds value to The Conjuring II film.

These additional scenes and stories are referred to as hyperreality in the film that ultimately creates a false reality and is trusted by society as a reality (Martadi, 2003). The Conjuring II has created a new reality and sensation for the real story of The Enfield Poltergeist and the participation in the Warren couple in handling the case of The Enfield Poltergeist. Thus the story of The Enfield Poltergeist and Warren couple has been commodified in such a way to make it an interesting story and has a high selling value in the market. 
James Wan as the director of The Conjuring II film not only focus on the real story of The Enfield Poltergeist, but also on the story of Ed and Lorraine Warren who was a Catholic demonologist. The Enfield Poltergeist story combined with the Warren couple story which means culture, customs, religion, and the things that are inherent in them will also be elevated into The Conjuring II film. The religious symbols of Catholicism, therefore, are featured in The Conjuring II. As James said in an interview with Sudhir Srinivasan from the Hindu news portal (http://www.thehindu.com/features/cinema/\%E2\%80\%98It\%E2\%80\%99s-more-than-just-a-horror-film\%E2\%80\%99/arti cle14384599.ece. Retrieved on 29 October 2017, 03:11 Western Indonesian Time) that:

"The Warrens couple has many fans; they also have a lot of skeptics. I think it's important to be featured in this film. The film is subjective, and told from the perspective of the Hodgson family in England, also the Warren couple. But I think it does not matter because it makes the storyline interesting. I really want to focus more on the Warren couple. I think The Conjuring works well because the audience really cares about them. I see that therefore The Conjuring II is more than a horror film"

Based on the statement of James Wan, the Warren couple reappointed in The Conjuring II film because of the large opportunities in attracting the audience. Warren couple's story has a high selling value. James Wan's statement shows that there is a political -economic goal in The Conjuring II film to maintain the popularity of The Conjuring film franchise. For the sake of reaching the greatest profit, the real story of The Enfield Poltergeist and the story of the Catholic Warren couple combined to create a film masterpiece that can be sold in the market. The Conjuring II became the highest-revenue film of the horror category of 2016 with gross domestic total earnings of $\$ 102,470,008$ and global revenues of $\$ 320,270.008$ with only a production expenditure of 40 million USD. The ratings and reviews provided by the audience on The Conjuring II film are also good which reaching 7.4 / 10 stars. (http://www.boxofficemojo.com/films/?id =conjuring2. htm. Retrieved on 8 September 2017, 21:43 Western Indonesian Time).

In addition to the true story of The Enfield Poltergeist and the Warren couple, the figure of a nun is also commodified in the form of a demon called Valak. The Valak character was so popular and inherent in the minds of the audience, which raises many questions among viewers ranging from the depiction of Valak resembling a nun, her immunity to the cross, and who the Valak really is. James Wan as director of The Conjuring II film answered the question in an interview with Germain Lussier, a reporter from GIZMODO io9 as follows. (https://io9.gizmodo.com/james-wanexplains-that-big-twist-in-the-conju ring-2-1781770378. Retrieved on 29 October 2017, 19:56 Western Indonesian Time) :

"By way of talking directly to Lorraine, she mentions the evil spirit in her house. And in a tornado with a hooded figure inside it. That made me think long enough to visualize it. And the idea came up all of a sudden. Since it was a vision of the demon that haunted Lorraine, and only attacked Lorraine, I wanted something that could strike her faith. Something that could threaten her husband's safety. And that's how the idea of the iconographic figure of the sacred icon formed in my mind."

Based on the statement of James Wan, the religious symbol of Catholicism is also used as one variable of the selling value of The Conjuring II film. Religious symbols of Catholicism such as the symbol of the cross and the nun actually have no role in the real story of The Enfield Poltergeist. There is no document showing any religious symbols of Catholicism in the real story of The Enfield Poltergeist. The purpose of Valak's appearance as a nun demon and wearing a cross necklace is to attack the faith of Lorraine. But because the film is a mass media product and public consumption, then the figure of Valak also has the potential to attack the faith of the entire audience of The Conjuring II film. 
The symbols of the cross and nuns are commodified in such a way in accordance with the market sense to add to the appeal of the film. The symbol of the cross is shown as an object with three meanings, which is believed to have the power to cast out evil spirits, possess the power to cast out evil spirits, and have no power to cast out evil spirits. The Commodification of the symbol of the cross is more emphasized on the meaning on the level of myth that is believed to have the power to cast out evil spirits. (https://forums.catholic.com/t/does-wearing-a-cross-protect-me-from-evil/111963. Retrieved on 15 November 2017, 14:34 Western Indonesian Time).

Whereas the meaning of the symbol of the cross in the true Catholicism ideology is not like that, but has a deep meaning namely 1) the unity of God the Trinity; 2) the cross denotes God's justice, which shows how cruel the consequences of our sin, that God himself redeemed it by his death on the cross (see Gal 3:13); 3) the cross denotes God's greatest love, that He laid down His life for us (Yoh 15:13) so that we may be saved and have eternal life (Yoh 3:16); 4) the cross which is a sign of salvation and victory of Christians, caused by Christ's victory over sin and death. (http://www.katolisitas.org/dalamnya-makna-tanda-salib/. Retrieved on 30 October 2017, 23:42 Western Indonesian Time).

Thus, the commodification of the cross symbol is a form of content commodification namely the transformation of meanings in the symbol of the cross into a new meaning in a product form that can be sold through The Conjuring II film. While the figure of a nun is commodified in the form of a demon nun named Valak. The figure of Valak is intentionally formed in such a way as to add to the attraction and uniqueness of the film, phenomenal as well as iconographic.

\section{Analysis of Disinformation}

A Commodification of the story of The Enfield Poltergeist, the Warren couple, the cross symbol and the nun included in the content commodification as messages and information were transformed into a new messaging system offered to the public as a commercial film product called The Conjuring II. The commodified messages, then lead to the abstraction of the communication function, the confusion of signs, the obscuring of meaning, the distortion of reality, and the eradication of truth called disinformation (Mufid, 2009). Commodification of content or story in The Conjuring II film has been produced in excessive portions until the communication conduct has no definite purpose and no longer have a clear meaning.

Based on the scene writers of The Conjuring II film, Chad and Carey Hills which both Christian told The Christian Post that they hope to spread the message that God will conquer evil. (https://www.christianpost.com/news/conjuring-2-christian-good-conquers-evil-interview-exclusive-clip-164931/.

Retrieved on 2 December 2017, 14:26 Western Indonesian Time):

"Conjuring II is a story from the perspective of those who believe in God whose strongest weapon is their faith in God. Believe in God, because God is the winner. Through Him, evil is defeated. This film is just one of millions of examples. For us, in addition to trust and faith in Jesus, the symbol of the cross represents the faith of those who hold it, hang it, or even as a tattoo. Some may have a Bible in their home and think they are protected, but without learning it further, and believe it, the Bible will be just like any other book. Just like the symbol of the cross. One must trust and believe what the symbol represents. " 
There is a positive message in The Conjuring II film to be conveyed to the audience that is about trust and faith in God. But the message of trust and faith in God is not delivered in the right way. Selection of stories, characters, until the symbols is displayed, selected because it has a selling value that can be offered to the audience. So the purpose of the making of The Conjuring II film is not purely based on the purpose to convey messages about trust and faith in God, but in fact has another goal to gain profit.

There is currently no definite boundary between truth and falsehood. Society is faced with great difficulties in separation between truth and falsehood. Truth in the mass media becomes crucial because media version truths are sometimes different from the public version because the application of truth in the media is influenced by the environment surrounding the media, such as capital owners and advertisers (Mufid, 2009). The Enfield Poltergeist story and Warren couple characters have distorted reality because they are not displayed according to the reality exist in the society.

While the symbols of the cross and nuns have led to the blurring of meaning because the meaning that is displayed is not the same every scene. Blurring means making things cannot be seen clearly, less real, less clear, and less settled. (https://kbbi.web.id/kabur. Retrieved on 7 September 2017, 16.58 Western Indonesian Time). The cross symbol is tends to show as a myth, while the nun is displayed with a negative connotation meaning. The location of the meaning of the cross symbol in The Conjuring II film is with the inconsistency of the meaning of the cross symbol displayed. The cross symbol in scenes 2 and 3 is shown as a myth that circulates in society, which is believed to have the power to cast out evil spirits. While in scenes 1, 4, and 5, the symbol of the cross is displayed only as a symbol without any power. Whether displaying the mythical symbol of the cross or simply as a symbol without meaning, both are equally obscure.

The nun character is interpreted as a woman who lives in a monastery or community, who pledge themselves to God's devotion and service in the church through three vows: vow of poverty, vows of virginity, and vow of obedience (Magis-Suseno, 2017). But with the appearance of Valak as a nun demon has changed the meaning of the positive connotation of the nun figure to a negative meaning. The nun who represents kindness and obedience to God is obscured to represent evil and opposition to God by being made a demon figure of a nun named Valak. Until finally the appearance of Valak as a nun demon made a product for entertainment and comedy by the community, such as Me-Me, selling nuns costumes for Halloween party, and so forth. This made the figure of a nun as if she was no longer as religious as ever.

When associated with messages of trust and faith in God in The Conjuring II film, then behind the meaning of the cross symbols displayed differently in each scenes has a purpose to distinguish between those who believe in the cross symbol with those who do not believe in the cross symbol. If one does not believe in the cross symbol as a symbol representing God, then the cross symbol is only a symbol. For Catholics, the cross symbol is interpreted as a religious symbol with profound meaning. Catholics believe in the cross symbol as a symbol of expression and representation of God. But for non-Catholics, the cross symbol does not necessarily have the same meaning as the meaning of the Catholics on the cross symbol. For non Catholics, the cross symbol is not necessarily in the faith as a symbol of expression and representation of God.

The different meaning of the cross symbols that occur between Catholics and non-Catholics can occur because between them undergoes a different symbolic process. A symbol can be understood if there is a community agreement called a symbolic process. The meaning of the cross symbol in scene 3 is shown to have the power to drive out evil spirits because the one holding the cross symbol is Ed Warren who is a devout Catholic. While on scene 1, 2, 4, and 5 cross symbols displayed no power to cast out evil spirits. In scene 1, Valak which is a demon certainly does not believe in the 
cross symbol as an expression and representation of God. Satan himself has the sense of being an angel who refuses to obey God (Magis-Suseno, 2017). So that the cross worn by Valak is not interpreted by Valak as interpreted by Catholics.

In scene 2, the crosses hanging on Janet's bedroom wall are shown to have no strength. The Hodgson family is not a religious family. This shows that the Hodgson family does not interpret and believe in the cross symbol as Catholics do. So the crosses in Janet's bedroom were nothing but hanging things on the wall. In scene 4, Bill Wilkins, who is an evil spirit also claimed to not believe in God while communicating with Ed in scene 3. The meaning of cross symbols displayed differently in The Conjuring II film is a different form of interpretation of each character in The Conjuring II film, between Catholics and non-Catholics.

Valak, which is a demon certainly contrary to the meaning of nun. Satan is an angel who refuses to obey God (Magis-Suseno, 2017). The angel meaning itself is a spiritual being created by God to proclaim God's will and protect man, no so as not to be caught by the five senses (Magis-Suseno, 2017). That way the demon also has the same form as the angel that is not bodied and not caught by the five senses. In the Bible, it is told in Corinth (11:14): "It should not be surprising, for the demon disguises himself as an angel of light." From that verse, the demon can be transformed into anything even a nun to plunge man into sin. When viewed more deeply, then the figure of Valak who look nuns and wearing a cross is not wrong because the demon can disguise into anything.

The Conjuring II film features the concept of faith in the film, as if trying to break the mythical symbol of the cross in society. However, the mythical symbol of the cross that is believed to have the power to cast out evil spirits is instead featured in The Conjuring II film, adding only the element of faith and trust in it. If a person does not believe in God, then the cross symbol does not have that power. This, too, is still obscure because the power of the cross to drive out evil spirits is a form of human faith. The Conjuring II film actually further perpetuates the mythical cross symbol by displaying it as a symbol that in the faith able to cast out evil spirits. As if to cast out the demons man must use the cross symbol. As it is written in the Bible that Jesus' way of casting out demons is not complicated. He uses His word alone. Therefore, Jesus emphasized the importance of prayer and fasting to drive out certain evil spirits. (http://www.katolisitas.org/iman-dan-praktek-iman-gereja-mengatasi-kuasa-kegelapa n/. Retrieved on 5 December 2017, 18:08 Western Indonesian Time). Thus, with or without the cross symbol, faith is the key of human power in the fight against evil spirits rather than on the belief in the representation contained in the cross symbol as the power of God.

\section{CONCLUSIONS}

The commodification and disinformation in The Conjuring II film consist of a commodification of The Enfield Poltergeist true story, the Warren couple, and the cross symbol and nun that are a form of content commodification. This is done to increase the attractiveness of the film and based on capitalist objectives to achieve maximum profits. The enormous revenues of The Conjuring II film indicate that the practice of commodification and disinformation has been successful. The character of Valak is made iconographic in order to be inherent in the minds of the audience and adds to the selling value as well as the uniqueness of the film.

Ultimately, the story of The Enfield Poltergeist and the Warren couple characters is distorted in reality because it is not displayed according to the reality contained in society and the cross symbols and the nun have led to the blurring of meaning because the meaning that is displayed is not the same as every scene. The cross symbol is actually displayed with a tendency to perpetuate the mythical symbol of the cross. While the nun who represents kindness and obedience to God, 
to be blurred because it is displayed as a figure of evil that represents evil and resistance to God.

The Conjuring II film gives a message to the audience that the cross symbol without faith is just a symbol. This is true, but still not quite right. Because with or without the cross symbol, faith is the key of human strength in the fight against evil spirits rather than on the belief in the representation contained in the cross symbol as a symbol that has the power of God. As Vincent Miller points out in his thesis "Consuming Religion" that the greatest threat to the culture of consumerism that makes Christianity a commodity is counter-value Christianity and the infected human capacity to understand what is valuable (in Conway, 2006). The commodification activity is often done to give additional characteristics or uniqueness for the production, but it is necessary to note the integrity of the story, the characters, and the symbols that are displayed so as not to cause negative impacts to society and the moral values are maintained.

\section{REFERENCES}

1. Barker, Chris. (2015). Cultural Studies: Theory and Practice (5th Edition). London: SAGE Publications Ltd.

2. Conway, Eamonn. (2006). The Commodification of Religion and The Challenges for Theology: Reflections From The Irish Experience. Bulletin ET. 17(1). 143-163.

3. Does Wearing A Cross Protect Me From Evil?. (2008). Retrieved on 15 November 2017, 14:34 Western Indonesian Time from https://forums.catholic.com/t/ does-wearing-a-cross-protect-me-from-evil/111963.

4. Film Semi-Dokumenter. (2012, August 6). From https://chirpstory.com/li/23262.

5. Ibrahim, Idi Subandy. (2011). Budaya Populer Sebagai Komunikasi: Dinamika Popscape dan Mediascape di Indonesia Kontemporer. Yogyakarta: Jalasutra.

6. Kabur. Retrieved on 7 September 2017, 16.58 Western Indonesian Time from https://kbbi.web.id/kabur.

7. Law, Jeannie. (2016). Horror Film 'The Conjuring 2' Seeks to Promote Christian Message, Good Conquers Evil (Exclusive Clip). Retrieved on 2 December 2017, 14:26 Western Indonesian Time from https://www.christianpost.com/news/conjuring-2christian-good-conquers-evil-interview-exclusive-clip-164931/.

8. Lussier, Germain. (2016). James Wan Explains That Big Twist in The Conjuring 2. $\quad$ Retrieved on 29 October 2017, 19:56 WIB from $\quad$ https://io9.gizmodo.com/james-wan-explains-that-big-twist-in-the-conjuring 2-1781770378.

9. Magis-Suseno, Franz. (2017). Katolik Itu Apa? Sosok-Ajaran-Kesaksiannya. Yogyakarta: PT. Kanisius.

10. Martadi. (2003). Hiper-Realitas Visual. Nirmana. 5(1). 80-95.

11. McQuail, Denis. (2010). McQuail's Mass Communication Theory. 6th Edition. London: SAGE Publications Ltd.

12. Mosco, Vincent. (2009). The Political Economy of Communication (2nd Edition). London: Sage Publications Ltd.

13. Mufid, Muhamad. (2009). Etika dan Filsafat Komunikasi. Jakarta: Kencana.

14. Srinivasan, Sudhir. (2016). It's More Than Just a Horror Film. Retreieved on 29 October 2017, 03:11 Western Indonesian Time from http://www.thehindu. com/features/cinema/\%E2\%80\%98I\%E2\%80\%99s-more-than-just-a-horrorfilm\%E2\% 80\%99/article14384599.ece.

15. Stefanus-Ingrid. (2017). Dalamnya Makna Tanda Salib. Retrieved on 30 October 2017, 23:42 Western Indonesian Time from http://www.katolisitas.org/dalamnya-makna-tanda-salib/.

16. Stefanus-Ingrid. (2017). Iman dan Praktek Iman Gereja Mengatasi Kuasa Kegelapan. Retrieved on 5 December 2017, 18:08 Western Indonesian Time from http://www.katolisitas.org/iman-dan-praktek-iman-gereja-mengatasi-ku asa-kegelapan/. 
17. Sugiyono. (2016). Memahami Penelitian Kualitatif. Bandung: Alfabeta, CV.

18. Sukmadinata. (2008). Metode Penelitian Pendidikan. Bandung: PT Remaja Rosdakarya.

19. The Conjuring. (n.d.). Retrieved on 8 September 2017, 18:43 Western Indonesian Time from http://www.boxofficemojo.com/genres/chart/?id=horrorperiod. $\mathrm{htm}$.

20. The Conjuring 2. (n.d.). Retrieved on 8 September 2017, 21:43 Western Indonesian Time from http://www.boxofficemojo.com/movies/?id=conjuring2.htm.

21. The Conjuring Vs The True Story of The Enfield Poltergeist. (2016). Diakses pada 10 October 2017, 23:44 Western Indonesian Time from http://www.historyvshollywood.com/reelfaces/conjuring-2-enfield-poltergeist

22. Vera, Nawiroh. (2014). Semiotika Dalam Riset Komunikasi. Bogor: Ghalia Indonesia.

23. Weber, Max. (2005). The Protestant Ethic and the Spirit of Capitalism. London: Routledge Taylor \& Francis Group.

24. Hidayatullah, Arsito. (2017). Ini 7 Jenis Konten Misinformasi dan Disinformasi. Retrieved on 8 September 2017, $20: 12$ Western Indonesian Time from https://www.suara.com/tekno/2017/05/15/232015/ini-7-jenis-konten-misinfor masi-dandisinformasi. 